\title{
АНАЛІЗ ПСИХОЛОГІЧНИХ ОСОБЛИВОСТЕЙ ПОДРУЖНЬОЇ ЗРАДИ НА РІЗНИХ СТАДІЯХ ФУНКЦІОНУВАННЯ СІМ'ї
}

Стаття присвячена теоретичному обтрунтуванню та емпіричному вивченню подружньої зради на різних етапах функціонування сім'ї. Проаналізовано особливості емоційного $i$ фізичного аспектів зради серед илюбних партнерів. Виявлено, щуо зі збільшенням подружнього стажу сексуальним стосункам приділяється менше уваги, в тому числі і парами з високою задоволеністю шлюбом. При цььому, у подружжів із низькою та середньою задоволеністю шлюбом частіше прослідковується прояв зради як з боку партнера, так і власної.

Встановлено, щуо рівень прояву защікавленості соимережами є досить високим серед подружніх пар на будь-якій стадії функиіонування сім'ї.

Ключові слова: подружня зрада, сімейна деструкція, психологічна сумісність, сексуальне благополуччя, гармонія подружніх взаємин, сексуальні зв'язки, особистісний профіль, задоволеність шлюбом.

Статья посвящена теоретическому анализу и практическому исследованию супружеской измены на разных этапах функционирования семьи. Проанализировано особенности эмоционального и физического аспектов измены среди супругов. Выявлено, что с увеличением супружеского стажа сексуальным отношениям уделяется менше внимания, в том числе, и парами с высокой удовлетворенностью браком. При этом, у супругов с низкой и средней удовлетворенностью семейными отномениями чаще прослеживается проявление измены как со стороны партнера, так и собственной. Доказано, что уровень проявления заинтересованностью сочсетями достаточно высок среди супружеских пар на любой стадии функционирования семьи.

Ключевые слова: супружеская измена, семейная деструкиия, психологическая совместимость, сексуальное благополучие, гармония супружеских отношений, сексуальне отношения, личностный профіль, удовлетворенность браком.

Постановка проблеми. У контексті складних і нестабільних реалій нашого суспільства психологи відзначають розмаїття тенденцій у сфері міжособистісної взаємодії й психології сім'ї. Існує значна кількість теоретичних положень, що породжують спектр концептуальних моделей міжособистісних взаємин і свідчать про актуальність осмислення психології сімейних взаємин, зокрема, особливостей гармонізації шлюбно-сімейних стосунків. Подружня гармонія складається 3 багатьох компонентів, серед яких визначальними вважають рівень культури та вихованість партнерів, індивідуальнотипологічні якості, національні традиції, звичаї, соціальні установки й цінності тощо. Гармонія в сім'ї включає також усі сторони міжособистісних стосунків, сексуальну та поведінкову відповідність. Статистика останніх років показує, що відсоток розлучень залишається стабільним і третина всіх шлюбів виявляється нежиттєздатними. Ці процеси пов'язані з демографічними, соціально-економічними і правовими змінами. Половина всіх сімей, що зберігають свій союз, належить до категорії проблемних, конфліктних і має потенційні причини розлучення.

Науковці стверджують, що важливе місце серед чинників успішності сім'ї займає сексуальне благополуччя в шлюбі. Досвід практичної роботи засвідчує, що гармонія подружніх взаємин залежить безпосередньо від ступеня задоволення потреб у взаємодопомозі, задоволенні почуття власної гідності, ласці, ніжності, турботі і увазі один до одного. Гармонія, створювана обома членами подружжя, зміцнює сім'ю, сприяє оновленню почуттів [4].

Аналіз останніх досліджень і публікацій. Постановка проблеми сімейних взаємин, трактування психологічних передумов їх розуміння та дослідження - актуальні завдання не 
лише за умови вказаної дослідниками кризи сучасної сім'ї й назрілими у зв’язку з цим психотерапевтичними завданнями, - психологічне розуміння сімейних стосунків матиме теоретичне та практичне значення як у плані досягнення благополуччя й стабільності сім'ї, так і для реалізації евристичних цілей наукового пошуку в ситуації влади інформаційних технологій, кризи суспільних систем [7]. Проблемі психології подружніх взаємин присвячені багаточисельні роботи як вітчизняних, так і зарубіжних дослідників (Т. Буленко; Л. Гозман, Е. Шлягіна; К. Імелінскій; Х. Каплан; М. Мушкевич). У них розглядаються такі проблеми сучасного шлюбу, як: психологічна сумісність партнерів, їх задоволеність шлюбом, структура сімейних ролей, проблема стійкості шлюбно-сімейних стосунків [3; 7]. На думку В. Сисенко, стійкість чи нестабільність шлюбу залежить від задоволення потреб партнерів. Науковець вважає, що для стабільності шлюбу значущим $\epsilon$ не лише задоволення матеріального становища подружжя, а й емоційно-психологічних потреб. Робер і Тільман стверджують, що в сім'ї існують сили згуртування, що чинять опір зміні структури, і сили розпаду, які призводять до змін. Рівновага існує в тому випадку, якщо сили згуртування переважатимуть над силами розпаду [6].

Зрада як варіант порушення подружнього життя суттєво відрізняється від інших видів сімейної деструкції: конфліктів, сварок, асоціальної поведінки, криз, розлучень та ін. Подружня невірність може зустрічатися у практично здорових, соціально благополучних сім'ях і бути відсутньою в зруйнованих. Область іiї прояву - сексуально-любовні стосунки подружжя, тоді як сварка, конфлікт, криза такої якісної визначеності не мають і можуть розвинутися у сфері побутових, економічних, батьківсько-дитячих та інших взаємин. Хоча зрада стосується не сімейних взаємин взагалі, а лише подружніх почуттів, проте в іiі переживання залучаються інші члени сім’ї, що завжди негативно відбивається на сімейній атмосфері в цілому, що може привести до серйозної кризи або розпаду шлюбу [2; 5].

Формулювання цілей статті. Мета дослідження полягає у встановленні особливостей позашлюбних сексуальних зв'язків на різних стадіях подружнього життя, емоційного і фізичного аспектів подружньої зради.

Дослідження передбачає вирішення наступних завдань:

1. Здійснити теоретико-методологічний аналіз проблеми психологічних аспектів подружньої зради.

2. Визначити особливості позашлюбних сексуальних зв'язків на різних стадіях подружнього життя.

3. Виконати емпіричний аналіз ставлення респондентів до емоційних та фізичних аспектів подружньої зради.

Виклад основного матеріалу дослідження. Як засвідчують дослідження М. Обозова, сучасний шлюб - це, перш за все, психологічний союз двох людей, духовно близьких, 3 однаковими ідеалами та ціннісними орієнтаціями. При цьому, на його думку, у партнерських стосунках отримання задоволення для себе неможливе без принесення насолоди партнерові як у взаєминах взагалі, так і в інтимній сфері [3]. Соціально-психологічні аспекти, на основі яких розвивається сім'я, містяться у особливостях особистості одного чи обох членів подружжя; розвитку подружніх взаємин; періоді виховання дітей; взаєминах партнерів; сексуально-інтимних розбіжностях; впливові батьків і близьких родичів; позашлюбних сексуальних зв'язках. Мова йде про досить широкий спектр обставин: особливостей соціального середовища, умов життєдіяльності сім’ї, змін в особистості одного з подружжя, які можуть ускладнити функціонування сім'ї. Через усі етапи сімейного циклу проходять так звані «нормативні стресори», тобто ті проблеми, які різною мірою переживаються усіма сім'ями: взаємна психологічна адаптація, формування стосунків з родичами при вирішенні житлової проблеми, догляд і виховання дитини тощо. Поєднання вищеназваних проблем в певні моменти життєвого циклу сім'ї може привести до сімейних криз $[1 ; 6]$.

Вибірку нашого дослідження склали 120 осіб (60 чоловіків та 60 жінок) - віком від 21 до 58 років. Стаж подружнього життя від 5 до 25 років. У всіх подружніх пар вибірки даний шлюб є першим. Для проведення дослідження нами було обрано низку психодіагностичних методик, спрямованих на аналіз особистісного і сімейного профілю. 3 метою визначення 
задоволеності шлюбом партнерами була використана методика «Задоволеність шлюбом» (В. Столін, Т. Романова, Г. Бутенко), що дозволяє визначити відношення особистості до власного шлюбу та рівень задоволеності подружніми взаєминами. Методика «Шкала любові і симпатії» (3. Рубін) використовувалась для дослідження рівня емоційних взаємин, зокрема, рівня любові й симпатії в шлюбних парах. Для підтвердження отриманих за вербальними методиками результатів ми використали у авторській версії методику незакінчених речень. Методика на визначення сексуальної самооцінки (К. Майяр). Тест містить чотири шкали: «Ваше тіло», «Близькі стосунки», «Багата фантазія», «Мистецтво еротики». Методика оцінки сексуального профілю (О. Потьомкіна), орієнтована на виявлення особливостей сексуальної поведінки у вигляді своєрідного профілю.

Одним із завдань дослідження було визначення задоволеності шлюбом подружніми парами вибірки. Отримані результати дали наступні показники: високий рівень задоволеності виявлено у $62,5 \%$ пар зі стажем до п'яти років, зі стажем від п'яти до п'ятнадцяти років показало 27,5 \% подружжів, 30 \% виявлено у партнерів, що перебувають у шлюбі від 15 до 25 років. Середні показники продемонстрували $25 \%$ подружніх пар із шлюбним стажем до п'яти років та 45 \% пар зі стажем від п'яти до п'ятнадцяти років; партнери з тривалістю подружнього від 15 до 25 років склали 37,5 \% . незадоволеними своїм подружнім життям виявились 12,5\% подружніх пар із шлюбним віком до п'яти років, 27,5\% пар - зі стажем від п'яти до п'ятнадцяти років та 32,5 \% подружжів зі стажем від 15 до 25 років. Отже, аналіз результатів дослідження задоволеності подружнім життям засвідчив, що із збільшенням сімейного стажу задоволеність шлюбом знижується, при цьому, задоволеність подружніми взаєминами у жінок на всіх етапах функціонування сім'ї, як правило, є нижчою.

Наступним етапом нашого дослідження було виявлення почуття любові та симпатії у досліджуваних 3 різним подружнім стажем. Результати дослідження показали, що чим менший стаж подружнього життя, тим вищими $є$ показники прояву любові до партнера. Заслуговує на увагу той факт, що почуття любові чоловіки продемонстрували вищими показниками, ніж жінки, на всіх етапах подружнього життя. При цьому, і чоловіки, і жінки засвідчили, що із збільшенням подружнього стажу в успішних сім'ях зростає симпатія до партнера. У подружніх парах із середнім та низьким рівнями задоволеності шлюбом зі збільшенням подружнього стажу почуття любові, як і прояв симпатії до партнера, і в чоловіків, і у жінок зменшується.

Ще одним етапом нашого дослідження було визначення особливостей сексуальної поведінки партнерів. Проаналізуємо результати за запропонованими методикою шкалами «Експресивність» характерна жінкам високого та середнього рівня задоволеності шлюбом. Їм притаманна сексуальна самооцінка групи «Ваше тіло»: сексуальність сконцентрована на власному тілі і залежить від нього. Високих показників набрали жінки зі стажем шлюбу до 5 років, із збільшенням подружнього життя дані зменшуються. Чоловіки зі стажем шлюбу до 5 років також набрали вищі показники, ніж інші категорії, проте дещо нижчі, ніж жінки. Сексуальна самооцінка у таких чоловіків залежить від близьких стосунків, довіри до партнера (група «Близькі стосунки»). «Сміливість» - низькі показники отримали чоловіки із високим рівнем задоволеності шлюбом та сексуальною самооцінкою групи «Багата фантазія». Такі особи надають перевагу віртуальному партнерові. «Вибірковість» - високі показники отримали жінки із високим та середнім рівнем задоволеності шлюбом та із подружнім стажем 5-15 років, дещо нижчі - до 5 років. У таких жінок переважає сексуальна самооцінка групи «Близькі стосунки» та «Ваше тіло». Вищі показники на всіх досліджуваних етапах отримали чоловіки із високими даними задоволеності шлюбом. Сексуальна самооцінка у більшості залежить від близьких стосунків, дещо менше від власного тіла та мистецтва еротики.

«Вразливість» є характерною для 59 \% усіх чоловіків, незалежно від задоволеності та стажу подружнього життя. Сексуальна самооцінка таких чоловіків, як правило, залежить від близьких стосунків, дещо менше - від власного тіла. Ще вищі показники (67 \%) набрали жінки на усіх трьох етапах нашої вибірки. Найбільше домінує сексуальна самооцінка, 
пов'язана із власним тілом, менше - із близькими стосунками, ще нижчі результати - iз мистецтвом еротики. Як у чоловіків, так і в жінок прослідковується інтерес до онлайнспілкування. «Ніжність» - високі бали набирають жінки зі стажем шлюбу до 5 років та від 5до 15 років з високим рівнем задоволеності шлюбом (78 \%) і мають приблизно однакові показники за сексуальною самооцінкою, тобто, сексуальні зв'язки залежать від власного тіла, близьких стосунків і мистецтва еротики. Низькі показники продемонстрували жінки 3 низьким рівнем задоволеності шлюбом на всіх рівнях. Серед чоловіків високі результати виявлені у 57 \% осіб зі шлюбом до 5 років - 3 високим рівнем задоволеності шлюбом, та 51 $\%$ - зі стажем від 5 до 15 років з високим рівнем задоволеності шлюбом. Подружжя із середнім та низьким рівнями задоволеності шлюбом продемонстрували досить низькі показники за параметром «ніжність». Сексуальна самооцінка в задоволених шлюбом переважає за параметрами «Ваше тіло», «Близькі стосунки», «Мистецтво еротики», в незадоволених - «Ваше тіло», «Багата фантазія». «Жертовність» - високі показники виявлено у жінок зі стажем шлюбу від 5 до 15 років із середнім та низьким рівнем задоволеності шлюбом. Домінуюча сексуальна самооцінка «Близькі стосунки». У чоловіків дуже низькі показники за всіма віковими категоріями. Сексуальна самооцінка залежить від усіх параметрів: власного тіла, близьких стосунків, багатої фантазії та мистецтва еротики.

«Відповідальність» - високі показники набрали чоловіки (56 \%) і жінки (68 \%) до 5 років шлюбного стажу з високим рівнем задоволеності шлюбом. Від 5 до 15 років і більше відповідальність зменшується незалежно від задоволеності шлюбом. Сексуальна самооцінка відносно рівномірна. «Любов» - отримані результати виявились аналогічними даним шкалі «Відповідальність». При цьому, у жінок до 5 років шлюбного стажу дещо вищі показники (73\%) ніж у чоловіків (61\%). «Різноманітність» - високі показники виявились у чоловіків (47\%) зі стажем від 5 до 15 років, дещо нижчі -в осіб чоловічої статі зі стажем від 15 до 25 років - $33 \%$, до 5 років стажу ці показники знизились до $12 \%$. У жінок дані розмістились наступним чином: до 5 років стажу - 7 \%, від 5 до 15 років $-24 \%$, від 15 до 25 років - $37 \%$.

У жінок зі стажем шлюбу до 5 років сексуальна самооцінка домінує за шкалами «Власне тіло», «Близькі стосунки» та «Мистецтво еротики». Значний відсоток даних категорії від 5-15 років та 15-25 років вибирають шкалу «Сексуальні фантазії» та надають перевагу спілкуванню 3 віртуальним партнером. «Небажаність» більш характерна для чоловіків $(67 \%)$ зі шлюбним стажем до 5 років, зі збільшенням подружнього стажу даний показник зменшується. Вплив задоволеності шлюбом для даної категорії осіб є незначним. За сексуальною самооцінкою розподіл виявився приблизно рівномірним за всіма категоріями. У жінок (73\%) виявили низькі показники за шкалою «небажаності сексуальних контактів на роботі», тобто вони не заперечують можливих виробничих сексуальних зв'язків.

Наступним етапом емпіричного дослідження було проведення тесту незакінчених речень $з$ метою виявлення ставлення подружніх пар до сексуальних стосунків на різних етапах функціонування сім’і. Як показали результати, зі збільшенням подружнього стажу сексуальним стосункам приділяється менше уваги, в тому числі, й парами із високою задоволеністю шлюбом. При цьому, пари з середнім та низьким рівнями задоволеності вважають, що зі збільшенням стажу функціонування сім'ї партнери віддаляються один від одного, байдужіють. Вони стверджують, що на погіршення сексуальних стосунків найбільший вплив має ставлення партнера, різноманіття в сексі, сприйняття тіла партнера. Прослідковується також виявлення зради партнером, про що свідчить відповідь такого змісту: «Мій сексуальний партнер часто намагається...» «...задовільнити сексуальні потреби на стороні». Разом з тим, такі пари стверджують, що на сексуальні стосунки та їх частоту, як правило, впливають взаємини, самопочуття дружини, вживання чоловіком алкоголю. Ставлення до віртуального спілкування у партнерів 3 низькою та середньою задоволеністю шлюбом є позитивним, вони, здебільшого, вважають, що соціальні мережі відволікають від буденності, підвищують адреналін, підсилюють сексуальний інтерес. При цьому, вважають, що емоційне захоплення онлайн-співрозмовником $є$ безневинною інтрижкою і на подружніх стосунках не відбивається. У подружніх пар з високим рівнем задоволеності шлюбом відповіді є дещо іншими. На їхню думку, із збільшенням подружнього стажу сім'я стає 
міцнішою, партнери мають більше уваги і підтримки. Вони вважають, що на сексуальні стосунки впливають взаємини між партнерами, емоційне забарвлення, тіло партнера та ін. Заслуговує на увагу той факт, що пари з високою задоволеністю шлюбом на усіх вікових періодах функціонування шлюбу більшу увагу приділяють спільному перегляду порнофільмів, ніж пари з низьким та середнім рівнями.

Отже, як бачимо із результатів дослідження, прояв зацікавленості та спілкування із онлайн-співрозмовниками протилежної статі збільшується із зниженням задоволеності подружніми взаєминами та сімейним стажем. При цьому, інтерес до такого спілкування $є$ характерним як для чоловіків, так і для жінок. Інтерес до онлайн-спілкування проявляють майже в однаковій мірі як чоловіки (59 \%), так і жінки (53 \%). Аналіз результатів ставлення партнерів до подружньої зради засвідчив, що серед пар із високою задоволеністю шлюбом $13 \%$ жінок і $26 \%$ чоловіків засвідчили факти зради своїм партнерам, 3 них до 5 років подружнього життя не виявлено жодної жінки, серед чоловіків - чотири особи, при цьому, із їхніх тверджень, свою зраду вони вважають випадковістю. Решта випадків відбулась на подальших стадіях функціонування шлюбу. Слід зауважити, що серед даної категорії опитуваних жодного випадку не виявлено, який би стверджував, що зрада була наслідком захоплення об'єктом протилежної статі. Разом з тим, серед подружніх пар із високими показниками задоволеності своїм партнером позитивне ставлення до онлайн-спілкування виявлене у 28 \% жінок і 43 \% чоловіків, при цьому лише у двох осіб жіночої статі і шести осіб чоловічої з подружнім стажем до п'яти років. Подружні пари із низьким та середнім рівнями задоволеності шлюбом відмінностей у ставленні до подружньої зради не продемонстрували.

Аналіз результатів дослідження подружніх пар зі стажем сімейного життя 5-15 років (рівень задоволеності - середній та низький) засвідчив, що 74 \% чоловіків і 36 \% жінок підтверджують факти зради своїм партнерам. При цьому, більшість з них вважають, що подружня зрада $\epsilon$ наслідком байдужості партнера та незадоволеності сексуальними стосунками в сім'ї. Слід зауважити, що $16 \%$ чоловіків і $19 \%$ жінок, свою зраду характеризують як тривале серйозне захоплення особою протилежної статі. Разом з тим, слід зауважити, що позитивне ставлення до онлайн-спілкування та активні пошуки об'єктів такого спілкування найбільш характерні саме даній категорії подружніх пар. Результати подружніх пар зі стажем подружнього життя до п'яти років виявили зраду партнерові чоловіками у 18 \% і жінками у 6 \%. При цьому, лише троє чоловіків і одна жінка стверджують, що це було (чи є) «серйозне» тривале захоплення особою протилежної статі. Інтерес до онлайн-спілкування проявляють майже в однаковій мірі як чоловіки (59 \%), так і жінки (53 \%). Як бачимо, жінки, які характеризують свої подружні взаємини як незадовільні, більш схильні до пошуку емоційних контактів, ніж фізичних. Чоловіки, у свою чергу, більш проявляють фізичну зраду партнерові, при цьому, також прагнуть до пошуків сексуальних партнерів поза сім'єю із тривалими стосунками.

3 метою виявлення залежності діагностованих від соціальних мереж нами була запропонована анкета із п'яти тверджень. Результати показали, що подружні пари із виявленим високим рівнем задоволеності на усіх етапах функціонування сім'ї перевагу надають пошуку цікавої інформації, спілкуванню з друзями, іграм. Партнери із низьким і середнім рівнями задоволеності шлюбом, на усіх періодах подружнього життя, виявили, окрім озвучених, підвищені інтереси до оновлення статусів, викладання нових фотографій, пошуку нових знайомств для спілкування. Як бачимо, рівень прояву інтересу до соціальних мереж на сьогоднішній день є досить високим серед подружніх пар на будь-якій стадії функціонування сім'ї. Проте зацікавленість у пошукові нових спілкувань, викладення власних фотографій здебільшого є характерними для подружжів із низькою та середньою задоволеністю сімейними взаєминами. Партнери, задоволені сімейним життям, надають перевагу різним додаткам, іграм, пошуку нової інформації, а також спілкуванню з друзями.

Висновки 3 даного дослідження і перспективи подальших розвідок. Теоретикометодологічний аналіз проблеми психологічних аспектів подружньої зради та проведене емпіричне дослідження дали змогу зробити наступні висновки. Із збільшенням подружнього 
стажу задоволеність сімейним життям знижується, при цьому, на всіх етапах функціонування сім’ї у жінок задоволеність взаєминами 3 партнером $є$ нижчою, ніж у чоловіків. Чим меншим є стаж подружнього життя, тим вищі показники прояву любові до партнера. Зі збільшенням сімейного стажу почуття любові зменшується, при цьому, у сім'ях 3 високою задоволеністю шлюбом зростає симпатія із кожним наступним досліджуваним етапом функціонування сім’ї. При цьому, чоловіки продемонстрували вищі показники прояву любові до партнера, ніж жінки, на всіх етапах функціонування сім’ї. У подружніх парах із середнім та низьким рівнями задоволеності шлюбом зі збільшенням подружнього стажу почуття любові, як і прояв симпатії до партнера, і в чоловіків, і у жінок зменшується. Зі збільшенням подружнього стажу сексуальним стосункам приділяється менше уваги, в тому числі і парами із високою задоволеністю шлюбом. Разом з тим, подружжя із середнім та низьким рівнем задоволеності стверджують, що зі збільшенням стажу функціонування сім’ї партнери віддаляються один від одного. У таким подружжях прослідковується також виявлення зради як з боку партнера, так і власної.

Прояв зацікавленості та спілкування із онлайн-співрозмовниками протилежної статі підвищується із зниженням задоволеності подружніми взаєминами та сімейним стажем. Як бачимо, рівень прояву інтересу до соціальних мереж на сьогоднішній день $є$ досить високим серед подружніх пар на будь-якій стадії функціонування сім'ї. Проте зацікавленість у пошукові нових спілкувань, отриманні емоційного задоволення, викладення власних фотографій здебільшого $\epsilon$ характерними для подружжів із низькою та середньою задоволеністю сімейними взаєминами. Партнери, задоволені сімейним життям, надають перевагу різним додаткам, іграм, пошуку нової інформації, а також спілкуванню з друзями.

У подальшому видається за доцільне вивчення особливостей дошлюбного сексуального досвіду і його зв'язку із готовністю партнерів до подружньої зради. Отримані у процесі дослідження результати та сформульовані висновки можуть бути успішно використані в практиці психологічного консультування подружніх пар, що потребують психологічної допомоги, та індивідуальній роботі з партнерами, таким чином сприяючи зміцненню інституту сім'ї.

\section{Список використаних джерел}

1. Андреева Т. В. Психология современной семьи : монография / Т. В. Андреева. СПб. : Речь, 2005. - 244 с.

2. Бондарчук О. І. Психологія сім'ї : курс лекцій / О. І. Бондарчук ; МАУП. - Київ, 2001. $170 \mathrm{c}$.

3. Дружинин В. Н. Психология семьи / В. Н. Дружинин. - 3-е изд., испр. и допов. СПб. : Питер, 2005. - 208 с.

4. Психологія сім’ї : навч. посіб. / В. М. Поліщук, Н. М. Ульїна, С. А. Поліщук та ін. ; за заг. ред. В. М. Поліщука. - 2-ге вид., допов. - Суми : Університ. кн., 2009. - 282 с.

5. Сатир В. Психотерапия семьи : пер. с англ. / В. Сатир. - СПб. : Речь, 2000.

6. Федоренко Р. П. Психологія молодої сім'ї та сімейна криза : монографія / Р. П. Федоренко. - Луцьк : РВВ «Вежа» Волин. нац. ун-ту ім. Лесі Українки, 2007. - 168 с.

7. Федоренко Р. П. Психологія сім'ї : навч. посіб. / Р. П. Федоренко. - Луцьк : ВежаДрук, 2015. - 364 с.

\section{References}

1. Andreeva T. V. Psihologija sovremenoj semji : monografija / T. V. Andreeva. $\mathrm{SPb}$. : Rech, 2005. - $244 \mathrm{~s}$.

2. Bondarchuk O. I. Psihilogija simji : kurs lekcij / O. I. Bondarchuk ; MAUP - Kyiv, 2001. $-170 \mathrm{~s}$.

3. Druzhinin V. N. Psihilogija semji / V. N. Druzhinin. - 3-e izd., ispr. i dopov. - SPb. : Piter, 2005. -208 s.

4. Psihilogija simji : navch. posib. / V. M. Polischuk, N. M. Ul'ina, S. A. Polischuk ta in. ; za zag. red. V. M. Polishchuka. - 2-e vid., dopov. - Sumy : Universit. kn., 2009. - 282 s. 
5. Satir V. Psychotherapija semji : per. s angl. / V. Satir. - St. Petersburg : Rech, 2000.

6. Fedorenko R. P. Psychologija molodoi simji ta simeina kruza : monografija / R. P. Fedorenko. - Lutsk : RVV "Vega" Volyn. Nats. un-th im. Lesia Ukrainka, 2007. - $168 \mathrm{~s}$.

7. Fedorenko R. P. Psychologija simji : navch. posib. / R. P. Fedorenko. - Lutsk : Vega-Druk, 2015. - 364 s.

\section{R. P. Fedorenko. ANALYSIS OF PSYCHOLOGICAL FEATURES OF ADULTERY AT DIFFERENT STAGES OF FAMILY FUNDATIONING.}

The article is devoted to theoretical justification and empirical study of adultery at different stages of family functioning. The features of emotional and physical aspects of adultery are analyzed.

One of the objectives of the study was to analyze the marital satisfaction over the family life cycle, as well as the association between the relationship satisfaction and a display of love and sympathy at different stages of marriage.

The results of the study showed that the longer family life cycle, the lower satisfaction with family life, while the shorter period of cohabitation, the higher the indicators of love. The analysis of sexual self-esteem has shown that both male and female levels of marital satisfaction do not play a significant role in this choice.

The longer family life cycle, the less attention is paid to sexual relations, including couples with a high marital satisfaction. At the same time, middle and low-satisfied spouses state that the longer marital experience, the sooner the partners are growing apart. These couples also tend to committing adultery.

It is noteworthy that the marital satisfaction decline and the growth of family life cycle of both men and women increases the interest and communication with online interlocutors of the opposite sex. At the same time, partners who are happy with married life, prefer playing games, searching for new information, communicating with friends to adultery.

Key words: adultery, family destruction, psychological compatibility, sexual well-being, harmony of marital relations, sexual relations, personality profile.

\section{ФІЗІОЛОГІЧНІ І ПСИХОЛОГІЧНІ АСПЕКТИ СОЦАЛЬНОЇ АДАПТАЦІЇ ДИТИНИ ДО ШКОЛИ}

Стаття присвячена аналізу фізіологічних $i$ психологічних аспектів соціальної адаптаиії дитини до школи. Готовність дитини до навчання визначається ї̈ фізичним $i$ психічним розвитком, станом здоров'я, розумовим і особистісним розвитком, тобто велике значення має весь комплекс факторів. У нашому дослідженні розглядається поняття соціальної зрілості як потреби дитини у спілкуванні з ровесниками та вміння підпорядковувати власну поведінку законам дитячих груп, а також здатність виконувати роль учня в ситуачії шкільного навчання. Схвалення вчителя має значний вплив на визначення потреби дитини в новій сочіальній позищї. Гарна поведінка та успішність у навчанні конструюють відносини із батьками та з товаришами по класу.

Ключові слова: адаптаџія, сочіалізаџія, школяр, навчання, розвиток, ровесники, вчитель, батьки.

Статья посвящена анализу физиологических и психологических особенностей социальной адаптации ребенка к обучению в школе. Готовность ребенка к обучению определяется его физическим и психическим развитием, состоянием здоровья, умственным и личностным развитием, то есть огромное значение имеет весь комплекс факторов. В нашем исследовании мы говорим о понятии соџииальной зрелости как необходимости в 